\title{
Prevalence of Malocclusion Among 6-15-Year-0ld Children in Georgia: Case Report
}

\author{
Maka Sabashvili* \\ Department of Dentistry, University of Georgia, Georgia
}

Received: 制 August 01, 2018; Published: 䟧 August 09, 2018

*Corresponding author: Maka Sabashvili, Administration of Rotational Learning School of Health Sciences and Public Health, University of Georgia, 77a Kostava Street, $1^{\text {st }}$ Building, Tbilisi, 0175, Georgia

\begin{abstract}
The study of prevalence of malocclusion is one of the common problem of orthodontics. Study of the epidemiological data on the prevalence of malocclusion is an important determinant in planning appropriate levels of orthodontic services. The occurrence of occlusal anomalies varies between different countries, ethnic and age groups. Also, malocclusions have a multifactorial origin and can hardly ever be attributed to a single specific cause. Causes include general factors, such as genetic and hereditary components, nutritional deficiencies and abnormal pressure habits or local factors located directly in the dental arch such as supernumerary teeth, tooth decay and premature loss of primary teeth. In patients with occlusion anomalies is important aesthetic complaints, which causes to inferiority complex. Analysis of Literature data confirms dental anomalies frequency around the world. Its frequency varies from $11 \%$ to $70 \%$. The objective of this study was to determine the prevalence of malocclusion among school children of Georgia. The sample consisted of 500 children (316 females, 184 males) in the age group of 6-15 years.
\end{abstract}

Keywords: Malocclusion; Prevalence; Dental Anomalies

\section{Introduction}

Epidemiological data, the malocclusion has the third highest prevalence among oral pathologies, second only to caries and periodontal disease. It is therefore in the third position of the scale of priorities as to the dental problems of Global Public Health, according to WHO [1]. Age is the main determinant for progress of any disease. In context to the specialty of Pedodontics and Orthodontics, some developing malocclusions may get selfcorrected with the progress of age. It is necessary to carry out epidemiologic studies of malocclusion in all regions at different age groups to grade the severity of malocclusion according to the respective age groups [2]. The causes that promote the evolution of this process are very diverse, which makes the malocclusion to be considered multifactorial, with hereditary, congenital, functional, environmental influences and nutritional, socioeconomic and educational factors [3]. The influences of harmful habits, among them, finger and pacifier sucking, are described in the literature [4] as a major etiologic factor of malocclusion in the phase of primary and mixed dentitions. Another factor worth mentioning is the presence and duration of breastfeeding. Children who are breast fed for at least 6 months, as recommended by WHO, tend to have lower prevalence of non-nutritive sucking habits, and if they are present, they will be shorter $[5,6]$.

Malocclusions i.e. dental occlusion problems are the result of orofacial adaptability to various etiological factors which result in various implications ranging from aesthetic dissatisfaction to changes in speech, mastication, swallowing, temporomandibular joint dysfunction and orofacial pain [7]. The epidemiological situation of the population is important for planning and implementation of preventive dental services and treatment [8]. Regarding the epidemiological data, the latest survey on Oral Health, known as SB Brazil 2003, had their data published by the Ministry of Health. Oral health planners in any country are often called upon to estimate the orthodontic problems and treatment need in their communities by measuring certain occlusal features that if untreated may lead to functional impairment [9] and aesthetic dissatisfaction [10]. As socioeconomic factors interfere significantly with oral health, developing nations still have problems with children suffering from early tooth loss mostly due to caries $[11,12]$.

Angle (1899) classified the malocclusion according to the relative position of the mandibular first permanent molar into class I at which the molar relationship is normal (buccal groove of the mandibular first molar is in line with the mesiobuccal cusp of the maxillary first molar but there is/are abnormalities within the arch like crowding, spacing etc.) and class II or distocclusion where the lower first molar is posteriorly positioned relative to upper molars. Class II can be further subdivided into division I where the upper incisors are proclined and division II where the upper central incisors are retroclined and lateral incisors are overlapping 
the centrals. Class III is the third classification and characterized by more anterior position of the lower molars relative to upper molars [11].

\section{Material and Methods}

The study was conducted based on the search of review articles deposited in international scientific databases (Scopus, Thomson Reuters, Google Scholar, Pubmed). The search strategy was elaborated taking into consideration the index of citation of concrete articles. Screening and selection of articles was performed according to actuality of topic and incidence of diseases. The sample consisted of 500 children (316 females, 184 males) in the age group of 6-15 years randomly selected in "Orthodontic Center" in Georgia.

\section{Results}

Table 1:

\begin{tabular}{|c|c|c|}
\hline Anomalies & $\mathbf{~ N}$ & $\mathbf{\%}$ \\
\hline Normal occlusion & 154 & 30.7 \\
\hline Malocclusion & 346 & $69.3 \%$ \\
\hline Crowding (lack of space in dental arch) & 128 & $24.7 \%$ \\
\hline Spacing of Teeth & 90 & $17.9 \%$ \\
\hline Other anomalies & 500 & $26.7 \%$ \\
\hline Total & 500 & \\
\hline
\end{tabular}
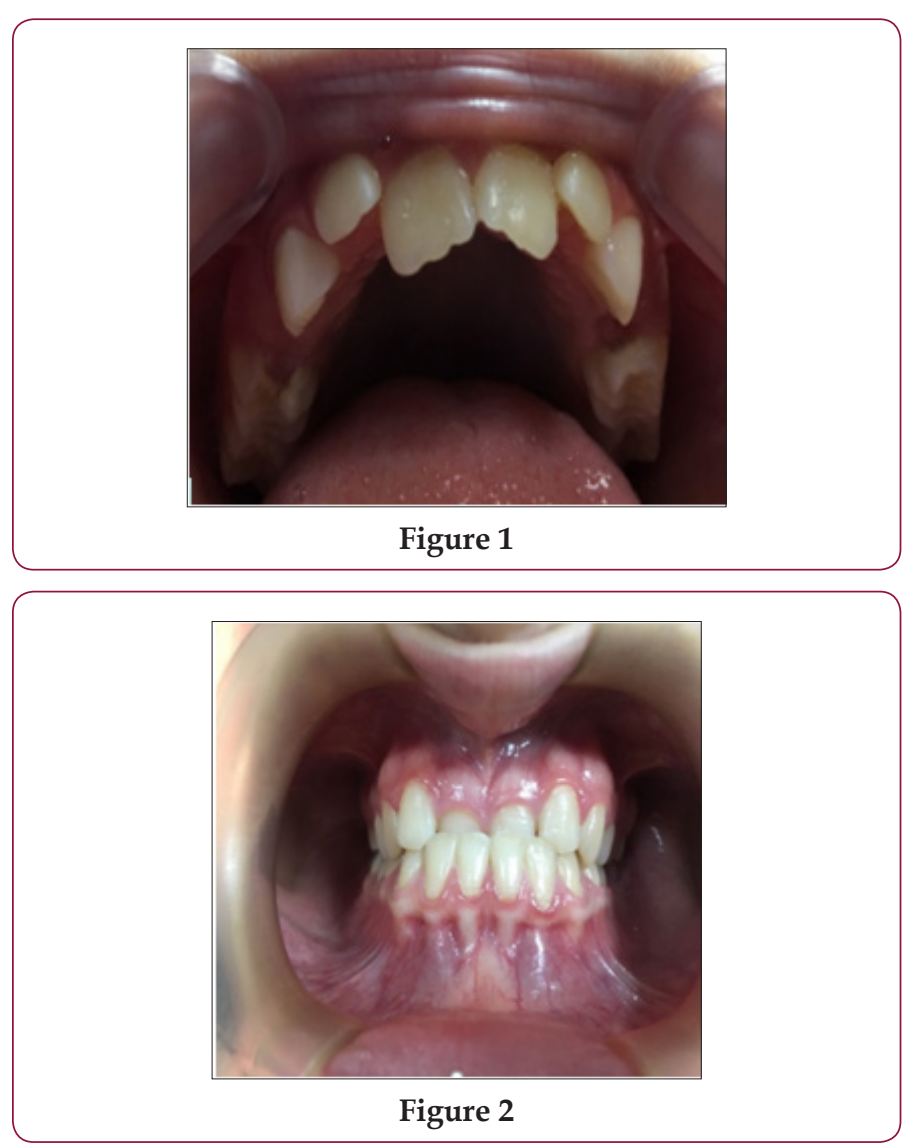

Table 1 shows the malocclusion of the subjects. Normal occlusions were found in $30.7 \%$ of subjects and $69.3 \%$ had malocclusions. Malocclusion is more often than other anomalies of teeth. It was especially high in the Crowding of teeth $(24.7 \%)$ (Figure 1). Crowding of teeth is often found in the upper jaw teeth groups. The reason may be the undevelopment of the jaw bone, hyperdontia, macrodontia, Congenital anomalies, harmful habits. Crowding of teeth causes many problems (Breathing, chewing). Also was high anomalies of Spacing of Teeth (17.9\%) (Figure 2). This anomaly can be found in the front part of the upper jaw. The causative factors are: Incompatibility of tooth size and jaw size, incorrect location of teeth, bad habits, congenital anomalies. Anomalies were recorded in equal numbers between boys and girls. In some cases, a few anomalies have been observed (Figures $3 \& 4$ ). As the picture shows, a 12-year-old girl has multiple dental anomalies.
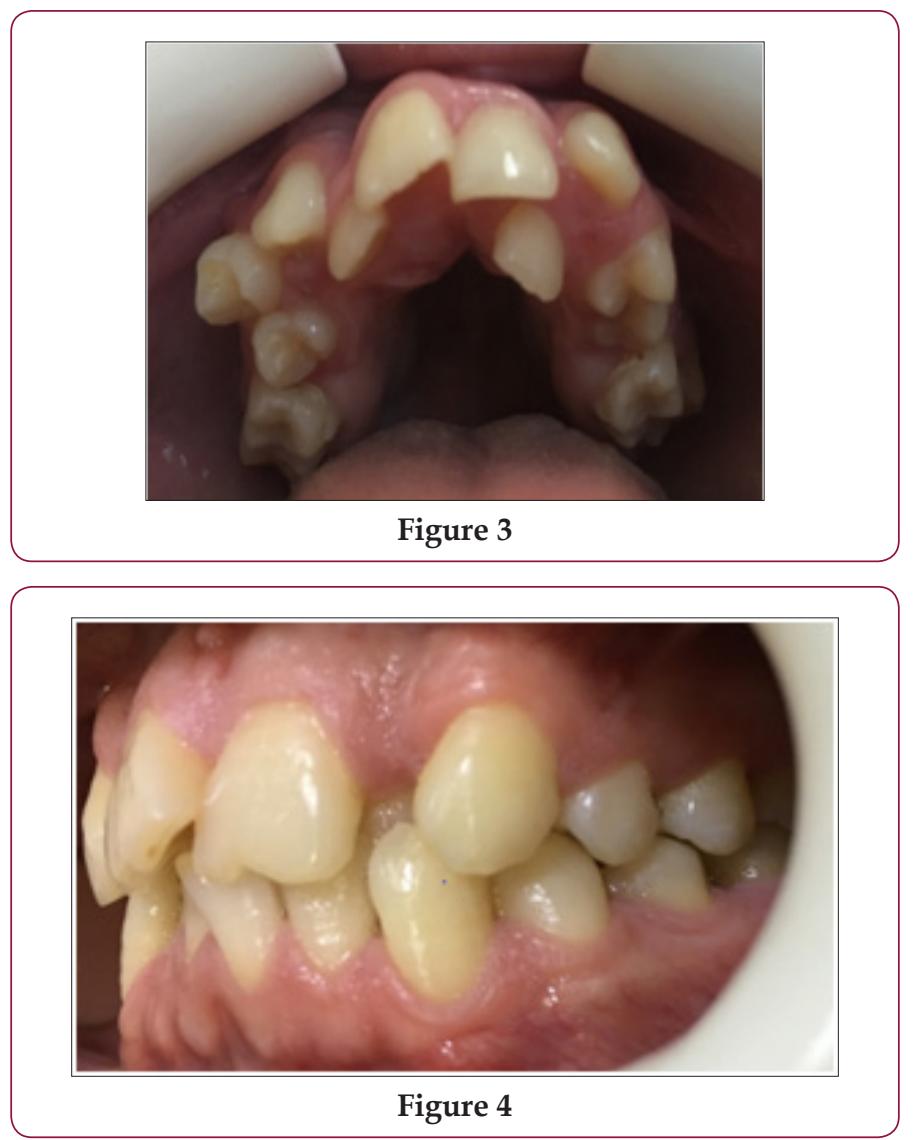

\section{Discussion}

The results showed that $69.3 \%$ of the children from 6 to 15 had malocclusion. Different ethnic groups have variable occlusal traits; it is not only prevalence and severity of malocclusion that fluctuates, but also the awareness, need for treatment and demand differ according to socioeconomic and cultural status of the population. In England, the orthodontic treatment need 34.8\% children from 6 to 18 years of age. In Turkey have been reported Orthodontic problems $37.77 \%$ in 6-10-years-old primary school children with a high socio-economic standard [12]. The study was conducted in India and in this study, it was observed a prevalence of $36.46 \%$ of malocclusion in population, classified as mild, moderate and severe. At the age of five, mild malocclusion was the most 
frequent $(22.1 \%)$, followed by moderate or severe $(14.5 \%)$. In children aged 12 , it was found $21 \%$ of very severe problems, which demonstrates that malocclusion may worsen with age, highlighting the importance of early treatment [9].

The highest scores of dental anomalies were seen among patients with Class II and Class III malocclusion. Most common occurring anomaly was rotation of teeth $(18.80 \%)$, followed by hypodontia (10.90\%) and most of the anomalies were observed in the mandibular arch. Hence, orthodontists should take this into consideration while planning treatment to reduce complications $[13,14]$. The reported prevalence of malocclusions is over $60 \%$ in preschool children and between 43 and 78\% in schoolchildren 14 . In older children and adolescents, crowded teeth due to space deficiency in the dental arches are frequent $[15,16]$. The normal occlusion score in Jequié was similar to that in Swedish $(26.4 \%)$ [17] and English children (26.8\%) [18]. In African-American children, it has been reported that $17 \%$ of the children had normal occlusion, while another study found prevalence of $16.6 \%$ in white American children. Other occlusal problems, anterior crossbite was found 5.7\% and open bite 13\% [19]. In Class I and Class III individuals, malocclusion prevalence dropped from 47.6 to $36.2 \%$ and from 8.2 to $3.7 \%$ [20]. The Latino population may be the largest minority group in the United States by the year 2004. This study analyzes the occlusion of 507 Latino adolescents between the ages of 12 and 18 years. More than 93\% of the subjects demonstrated some form of malocclusion [21,22].

\section{Conclusion}

As the study showed, in Georgia was observed high incidence of dental anomalies stand and malocclusion. The study revealed that they causes many social and functional problems. The results also showed that the reasons of malocclusion is bad habits and congenital anomalies. Exact and fast treatment is very important for future results.

\section{References}

1. Organização Mundial da Saúde (1991) Levantamento epidemiológico básico de saúde bucal: manual de instruções. (3 ${ }^{\text {rd }}$ Edn.). São Paulo: Ed Santos.

2. Roopa Siddegowda, Rani MS (2013) Assessment of Malocclusion in school children of Karnataka State between the age groups of 10-12 years and 13-16 years. IOSR Journal of Dental and Medical Sciences 11(3): 06-12.

3. Roncalli AG (2005) epidemiologia: um olhar coletivo sobre a saúde bucal. In: Ferreira A et al. (Org.). Saúde bucal coletiva: conhecer para atuar. Natal: Ed. da UFRN cap 3: 39-62.

4. Carvalho CM, Carvalho LFPC, Forte FDS, Aragão MS, Costa LJ (2009) Prevalência de mordida aberta anterior em crianças de 3 a 5 anos em Cabedelo/ PB e relação com hábitos bucais deletérios. Pesq Bras Odontoped Clin Integr 9(2): 205-210.

5. Furtado ANM, Vedovello Filho M (2007) Influência do período de aleitamento materno na instalação dos hábitos de sucção não nutritivos e na ocorrência de maloclusão na dentição decídua. RGO 55 (4): 335341 .

6. Souza DFRK, Valle MAS, Pacheco MCT (2006) Relação clínica entre hábitos de sucção, má oclusão, aleitamento e grau de informação prévia das mães. Revista Dental Press Ortodon Ortop Facial 11(6): 81-90.

7. PROFFIT, WR (2002) Etiologia dos problemas ortodônticos. In: Ortodontia contemporânea. ( ${ }^{\text {rd }}$ Edition). Rio de Janeiro: Guanabara Koogan pp. 105-134.

8. Brito DI, Dias PF, Gleiser R (2009) Prevalência de más oclusões em crianças de 9 a 12 anos de idade da cidade de Nova Friburgo (Rio de Janeiro). R Dental Press Ortodon Ortop Facial 14(6): 118-124.

9. (2003) Brasil Ministério da Saúde, Coordenação Nacional de Saúde Bucal. Condições de saúde bucal da população brasileira. Brasília, DF, 2004 Projeto SB Brasil.

10. Ayhab B Alatrach, Fayez K Saleh, Esam Osman (2014) The Prevalence of Malocclusion and Orthodontic Treatment Need In A Sample Of Syrian Children. European Scientific Journal 10(30): 1857-7881.

11. Angle EH (1899) Classification of Malocclusion. Dental cosmos 41: 248264.

12. Ibrahim Erhan Gelgor, Ahmet Arif Celebi (2013) Prevalence of Malocclusion and ortodontic treatment need in Turkish adolescents. Journal of Society for development in new net environment in B\&H.

13. Fejerskov O, Baelum V, Luan WM, Manji F (1994) Caries prevalencein Africa and the People's Republic of China. Int Dent J 44(1): 425-233.

14. Kock G, Martinsson T (1970) Socio-odontologic investigation ofschool children with high and low caries frequency. I Socio-economic background. Odontol Revy 21: 207-216.

15. KS Dwijendra, Vishal Parikh, Soja Sara George, Gururam Tej Kukkunuru, Gali Nagarjuna Chowdary (2015) Association of Dental Anomalies with Different Types of Malocclusions in Pretreatment Orthodontic Patients. Journal of International oral health 7(6): 61-64.

16. Köhler L, Holst K (1973) Malocclusion and sucking habits of four-yearold children. Acta Paediatrica Scandinavica 62: 373-379.

17. Sidlauskas A, Lopatiene K (2009) the prevalence of malocclusion among 7-15-year-old Lithuanian schoolchildren. Medicina (Kaunas, Lithuania) 45(2) 147-152.

18. Bourzgui F, Sebbar M, Hamza M, Lazrak L, Abidine Z El Quars F (2012) Prevalence of malocclusions and orthodontic treatment need in 8 to 12 -year-old schoolchildren in Casablanca, Morocco. Progress in Orthodontics 13(2): 164-172.

19. Ricardo Alves de Souza, Maria Beatriz Borges de Araújo Magnani, Darcy Flávio Nouer, FábioLourenço Romano; Manuela Ribeiro Passos (2008) Prevalence of malocclusion in a brazilian school children population and its relationship with early tooth loss. Braz J Oral Sci 7(25): 1566-1570.

20. Haynes S (1970) The prevalence of malocclusion in English school children aged 11-12 years. Eur Orthod Soc Trans 48: 89-98.

21. Amos AL, Gasparetto A, Terada HH, Furquim LZ, Basso P, Meireles RP (2000) Assistência Ortodôntica Preventiva-Interceptoraem escolares do município de Porto Rico -Parte 1: prevalênciadas más-oclusões. Rev Dental Press Ortodon Ortop Facial 5: 9-13.

22. Rebeka G Silva, David S Kan (2001) Prevalence of malocclusion among Latino adolescents. American Journal of Orthodontics and Dentofacial Orthopedics 119(3): 313-335. 
ISSN: 2574-1241

DOI: 10.26717/BJSTR.2018.07.001553

Maka Sabashvili. Biomed J Sci \& Tech Res

(C) (i) This work is licensed under Creative

Submission Link: https://biomedres.us/submit-manuscript.php

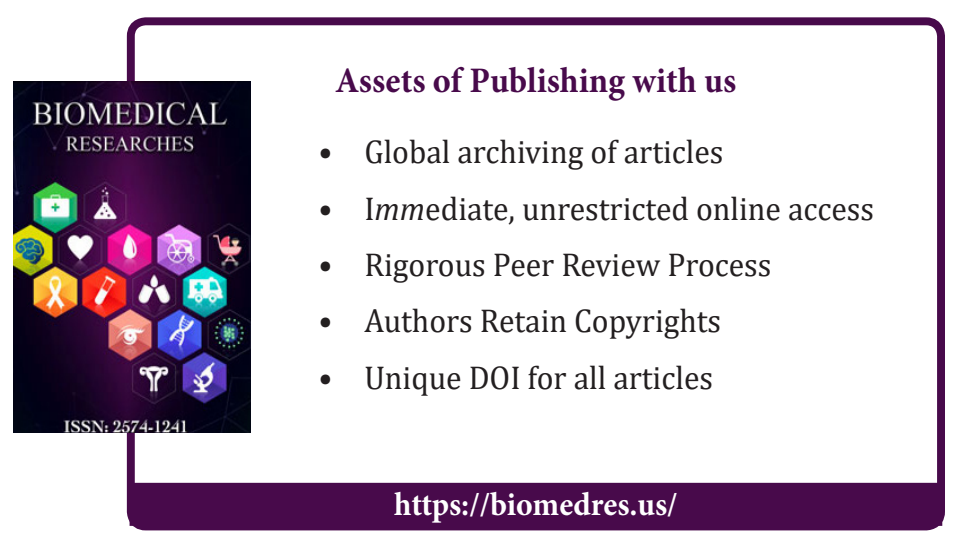

